\title{
ОГЛЯД
}

УДК 578.834.1: 616.91: 616.24-001: 541.134.5

DOI 10.11603/mcch.2410-681X.2021.i1.12119

\author{
О. С. Покотило ${ }^{1}$, М. М. Корда ${ }^{2}$, Ю. С. Кравчук ${ }^{2}$ \\ ТЕРНОПІЛЬСЬКИЙ НАЦІОНАЛЬНИЙ ТЕХНІЧНИЙ УНІВЕРСИТЕТ ІМЕНІ ІВАНА ПУЛЮЯ \\ ТЕРНОПІЛЬСЬКИЙ НАЦІОНАЛЬНИЙ МЕДИЧНИЙ УНІВЕРСИТЕТ ІМЕНІ І. Я. ГОРБАЧЕВСЬКОГО \\ МОЗ УКРӒ̈НИ
}

\section{РОЛЬ МОЛЕКУЛЯРНОГО ВОДНЮ ТА ОКСИДУ АЗОТУ В ПАТОГЕНЕЗІ COVID-19}

Вступ. У статті наведено огляд наукової літератури щодо біохімічної ролі двох молекул, таких, як молекулярний водень та оксид азоту, насамперед при COVID-19 - вірусній інфрекції, яка може бути летальним захворюванням для людей з ослабленим імунітетом. Результати численних доклінічних та клінічних досліджень продемонстрували, що газоподібні молекули (молекулярний водень та оксид азоту) мають антиоксидантні, протизапальні й імуномодулюючі переваги. Незважаючи на те, що оксид азоту може безпосередньо знешкоджувати патогени, чим розкриває свою визначальну роль для імунної функції, оскільки може інгібувати реплікацію вірусів, він здатний також спричинювати летальне ураження клітин за стресових умов, зокрема при COVID-19. На відміну від оксиду азоту, молекулярний водень має дуже високий ступінь безпечності, допомагає регулювати вироблення оксиду азоту, його метаболізм і послаблює його шкідливий вплив. На сьогодні ще не розкрито всіх точних молекулярних механізмів молекулярного водню, проте вже відомо, що він забезпечує ряд захисних ефектів, модулює передачу сигналу, впливає на експресію генів та змінює каскади білкового фросфрорилювання. Через чі доведені ефекти молекулярного водню можна однозначно кваліфрікувати його як оптимальну терапію проти COVID-19 та подібних захворювань. Обидві молекули (молекулярний водень та оксид азоту) використовують у доклінічних і клінічних випробуваннях для розкриття біохімічних та патогенетичних механізмів взаємодії при різних патологічних процесах, у тому числі й при COVID-19.

Мета дослідження - проаналізувати сучасні літературні джерела про вплив молекулярного водню та оксиду азоту на запобігання поліорганній недостатності при COVID-19.

Висновки. Збільшення кількості досліджень дає підстави сподіватися, що в майбутньому результати представлених досліджень матимуть практичне застосування у клінічній медицині. На сьогодні ще необхідно з'ясувати механізми позитивного впливу молекулярного водню при різних патологічних станах, у тому числі при COVID-19. Тому дослідження мають актуальний характер і будуть продовжені.

КЛЮЧОВІ СЛОВА: COVID-19; молекулярний водень; воднева вода; оксид азоту; окиснювальний стрес.

COVID-19 - це інфрекційне захворювання, спричинене тяжким гострим респіраторним синдромом коронавірусу 2 (SARS-CoV-2), результатом якого стала поточна пандемія коронавірусу 2020-2021 рр. [1]. Хоча вірус може завдати шкоди різним органам, найбільше при цій хворобі страждають легені. Маючи такі грипоподібні симптоми, як лихоманка, втома та задишка, COVID-19 може також прогресувати до пневмонії, поліорганної недостатності й навіть смерті [1]. Це є наслідком клітинних аберацій, спричинених патогеном, які в подальшому виникають і призводять до реакцій окиснювалього та запального стресу. За умови, що імунна система може перемогти інфекцію, супутнє ушкодження багатьох органів може викликати додаткові ускладнення та збільшує ймовірність летальності. Тому (с) О. С. Покотило, М. М. Корда, Ю. С. Кравчук, 2021. активна реакція-відповідь імунної системи і відповідна виражена запальна та окиснювальна реакція є очевидними й адекватними щодо ситуації з COVID-19. На сьогодні лише починають упроваджувати вакцини, які через брак часу ще не мають достатнього доклінічного підтвердження їх еорективності, а з іншого боку, відсутній уніфрікований єдиний протокол ефективного медичного втручання для лікування COVID-19 [1]. Однак, поряд з багатьма варіантами використання різних лікарських препаратів, які тестують, після проведення принаймні чотирьох клінічних досліджень застосування молекулярного водню у пацієнтів, які страждають від COVID-19, було отримано позитивні попередні результати.

Молекулярний водень та імунна фрункція.

Молекулярний водень $\left(\mathrm{H}_{2}\right)$ - це легкозаймистий газ, який не має запаху, легко дифузується, 
в організмі його природним чином виробляють кишкові бактерії [2]. У ранній публікації в Science 1975 р. M. Dole та співавтори повідомили про те, що гіпербаричний водень є ефективним засобом лікування плоскоклітинного раку в мишей-альбіносів [3]. У пізнішій публікації в Nature Medicine 2007 р. показано, що вдихання $\mathrm{H}_{2}$ помітно зменшувало ушкодження мозку на моделі інсульту щурів, пригнічуючи окиснювальний стрес та запалення [4]. Подальші наукові публікації (на сьогодні приблизно 2000) та клінічні випробування на людях (близько 100) від університетів і установ усього світу ще більше підтвердили початковий висновок про те, що $\mathrm{H}_{2}$ має терапевтичний ефрект [5].

Молекулярний водень вводять людям переважно розчиненим у воді або аераційно [5]. В Японії його використовують для лікування синдрому зупинки серця, що підтверджено на основі клінічних досліджень у 360 пацієнтів [6]. Молекулярний водень має антиоксидантну, протизапальну, протиалергічну й антиапоптичну захисну дію. Хоча точні молекулярні механізми залишаються нерозкритими, $\mathrm{H}_{2}$ забезпечує дані захисні ефекти, модулюючи передачу сигналу, впливаючи на експресію генів та модулюючи каскади білкового фросфорилювання [5]. Ці доведені ефекти молекулярного водню можна однозначно кваліфрікувати як оптимальну терапію проти COVID-19 та подібних захворювань. На сьогодні, на основі результатів експериментальних і клінічних досліджень, $\mathrm{H}_{2}$ вже запропоновано як еорективний засіб для лікування множинної дисфрункції органів, викликаної грипом та іншими вірусними інфекційними захворюваннями [7, 8].

Наприклад, на моделі системного запалення у щурів, спричиненого ліпополісахаридом, насичена воднем вода суттєво знижувала рівень прозапальних медіаторів у плазмі крові, а саме фрактора некрозу пухлин- $\alpha$, простагландину $\mathrm{E}_{2}$, інтерлейкіну (IL) 6, і підвищувала вміст протизапального цитокіну - IL-10. В інших дослідженнях показано, як $\mathrm{H}_{2}$ симптоматично запобігав індукованій ліпополісахаридом гіпотонії, лихоманці [9], нейрозапаленню та сприяв одужанню від індукованої ліпополісахаридом хвороби [10].

Терапія молекулярним воднем ефективно зменшувала викликані радіацією ушкодження імунної системи, попереджуючи зниження кількості спленоцитів і CD4+ Крім того, він запобігав індукованому радіацією дисбалансу між клітинами Th1, Th2, Th17 i Treg, а також іншими цитокінами (фактор некрозу пухлин- $\alpha$, трансорормуючий фрактор росту- $\beta 1$, гранулоцитарно-макрофагальний колонієстимулювальний фрактор, IL-1 $\beta$, IL-4, IL-5, IL-10,
IL-17, IL-23) [11]. Подібним чином у клінічному дослідженні на 55 пацієнтах 3 раком прямої кишки IV стадії інгаляція молекулярним воднем відновила нормальний рівень CD8 ${ }^{+}$Т-клітин [12]. Ці цитотоксичні Т-лімфоцити націлені на клітини, інфріковані раком та вірусами [13]. Результати іншого рандомізованого клінічного дослідження на 60 пацієнтах із хронічним гепатитом В показали, що приймання водневої води впродовж 6 тижнів зменшувало окиснювальний стрес і мало тенденцію пригнічувати рівень вірусної ДНК та покращувати функції печінки [14].

Також продемонстровано, що пероральне приймання водневої води усувало алергічну реакцію негайного типу в мишей та запобігало дегрануляції опасистих клітин шляхом пригнічення активності НАДФН-оксидази [15]. Пізніше було встановлено, що насичена молекулярним воднем вода зменшує вироблення гамма-індукованого оксиду азоту (NO*) у макрофрагах, які утворюють молекулярну основу для функціональної взаємодії між цими двома сигнальними молекулами [16]. Очевидно, механізми, які відповідають за ці протизапальні й антиоксидантні ефекти, принаймні частково включають здатність молекулярного водню значно пригнічувати індукцію запалення NLRP3 [17] та активувати Nrf2-антиоксидантний шлях [5] і цитопротекторну гемоксигеназу-1 [18]. Висока клітинна біодоступність молекул $\mathrm{H}_{2}$, їх імуномодулююча активність у поєднанні зі здатністю відновлювати гомеостаз і забезпечувати регуляцію цитокінів (тобто запобігати чи послаблювати цитокіновий шторм) дають їм значну перевагу серед інших терапевтичних чинників [5].

Оксид азоту й імунна фрункція.

Подібно до молекулярного водню, оксид азоту також є газоподібною сигнальною молекулою. Оксид азоту давно визнано одним 3 найбільш універсальних та ключових регуляторів імунної системи. Він бере участь у патогенезі й контролі автоімунних процесів та інфекційних захворювань [19]. Крім того, було показано ефективну здатність молекулярного водню пригнічувати цикл реплікації тяжкого гострого респіраторного синдрому COVID-19 in vitro [20]. Одночасно оксид азоту оцінювали клінічно у пацієнтів з COVID-19.

Оксид азоту в основному виробляється за допомогою синтази оксиду азоту (NOS), що має три ізоформи, а саме: ендотеліальну (eNOS, або

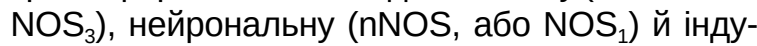
цибельну (iNOS, або $\mathrm{NOS}_{2}$ ) [21]. Амінокислота аргінін метаболізується цим ензимом з утворенням NO• та цитруліну. Рівень NO• поступово знижується з віком, навіть до 75 \% у 70-80-річних порівняно зі здоровими 20-річними [22]. Надмір- 
ні запальні стани призводять до поліорганної дисорункції внаслідок неправильного розподілу кровотоку та порушення мікроциркуляції [21]. Це відбувається через дефіцит NO` у необхідних місцях із надмірним виробленням у непотрібних місцях. Доступність аргініну часто суттєво погіршується при запальних станах, наприклад у пацієнтів із сепсисом [21]. Дефріцит аргініну може виникнути через його підвищений катаболізм та обмежену доступність цитруліну, який використовується для синтезу аргініну de novo. Оскільки навіть за нормальних умов аргінін швидко метаболізується, результати досліджень показують, що добавки цитруліну ефективніше підвищують рівні аргініну та NO у плазмі крові порівняно 3 добавками аргініну [23]. Низький рівень цитруліну пов'язаний із гострим респіраторним дистрес-синдромом, а також може призвести до диссрункції NOS, що спричинює подальші окиснювальні та клітинні ураження [24].

Молекулярна комбінація водню та оксиду азоту.

Оксид азоту як реактивний вільний радикал сприяє виживанню або загибелі клітини залежно від його концентрації, місця розташування і часу синтезу. Важливо, що молекулярний водень регулює рівень NO` за рахунок як зменшення надмірного вироблення (наприклад, у результаті пригнічення активності iNOS), так і його збільшення (наприклад, через посилення активності eNOS) [5]. Таким чином, регулювання молекулярним воднем NO* має вирішальне значення: з одного боку - для посилення його корисних терапевтичних ефектів, а з іншого - для пом'якшення шкідливих наслідків. Оксид азоту майже миттєво реагує із супероксидом $\left(\mathrm{O}_{2}^{--}\right)$, утворюючи згубний пероксинітрит (ONOO-), який є надзвичайно окисною і цитотоксичною молекулою [25]. Реакція з $\mathrm{O}_{2}^{-}{ }^{-}$безпосередньо зменшує доступність циркулюючого NO', що ще більше погіршує стан хворого [25]. Радикали, $\mathrm{O}_{2}{ }^{--} \mathrm{i} \mathrm{NO}$, відіграють важливу корисну роль в імунній системі, включаючи знищення патогенних мікроорганізмів, у тому числі вірусів, пригнічують їх реплікацію та регулюють запальну реакцію організму. Однак за стресових умов, таких, як COVID-19 і його прогресування до пневмонії, поліорганної недостатності й інших ускладнень, ці молекули втрачають здатність до критичного регулювання та роблять свій уже негативний внесок в етіологію і патогенез даного захворювання. Це спричинено утворенням ONOO- івкрай токсичного гідроксильного радикала ('OH) [25]. Доведено, що молекулярний водень сприятливо регулює вироблення $\mathrm{O}_{2}^{--}$і $\mathrm{NO}$, впливаючи на НАДФН-оксидазу та ізоформи (iNOS, eNOS, nNOS) [5]. Крім того, $\mathrm{H}_{2}$ може ефрективно знижу- вати рівень токсичних гідроксильних та пероксинітритних окиснювачів [4]. До того ж, комбінована терапія $\mathrm{NO}$ ` $\mathrm{Ha}_{2}$ продемонструвала позитивний синергетичний ефект на моделі гострого ураження легень, яке виникає при COVID-19. Таке комбіноване лікування значно зменшувало рівень нейтрофілів у легенях, запалення та апоптоз, спричинені ліпополісахаридом і полімікробним сепсисом [26]. Крім того, $\mathrm{H}_{2}$ запобігав ушкоджувальній дії NO;, що підтверджувалося елімінацією рівня нітротирозину, і спостерігали це лише при терапії NO• [26].

Доведено, що молекулярний водень зменшував запалення дихальних шляхів у алергічних астматичних мишей [27]. В іншому дослідженні у хворих на астму показано ефрективне полегшення від приймання молекулярного водню, яке мало більший терапевтичний ефект при одночасному прийманні 3 NO^-стимулювальним продуктом [28].

Як згадувалося раніше, оксид азоту також сприяє кровотоку, індукуючи розширення судин. Оптимальна перфуззія крові $€$ критично важливою для нормальної роботи органів, загоєння ран та виконання фрізичних вправ. Вона забезпечує клітини киснем, поживними речовинами, гормонами, іншими метаболітами, а також видалення шкідливих продуктів обміну речовин. Як і рівень оксиду азоту, приплив крові до тканин і клітин теж зменшується з віком [29], що може сприяти нейродегенерації, нейропатії [30] та порушенням фрункції імунної системи [31]. В окремому дослідженні показано, що споживання водневої води з високою концентрацією молекулярного водню може покращити фрункцію ендотелію та значно збільшити опосередковану потоком дилатацію плечової артерії [32].

Таким чином, біомедичні ефекти молекулярного водню та оксиду азоту на сьогодні достатньо обґрунтовано в науковій літературі. Очевидним стає фракт, що ці молекули були добре апробовані під час доклінічних та клінічних досліджень і мали широкий спектр терапевтичних ефректів. На клітинному рівні COVID-19 та подібні захворювання характеризуються порушенням регульованої запальної реакції імунної системи, надмірним окиснювальним стресом та порушенням клітинної функції загалом. Оксид азоту відіграє подвійну роль у фрункціонуванні імунної системи, з одного боку, він бере участь у знищенні патогенних мікроорганізмів, гальмуванні їх реплікації, а з іншого - сприяє окиснювальному ураженню клітин та стимулює надмірне запалення [33]. Враховуючи те, що оксид азоту відіграє ключову роль у забезпеченні фрункцій здорової клітини, інгібування або активація ізоформ NOS за допомогою фрармакологічного 
втручання має також як корисні, так і шкідливі наслідки [25]. Молекулярний водень, навпаки, $€$ новим та безпечним медичним газом, який проявляє терапевтичні ефректи, регулюючи окиснювально-відновний стан і запальну реакцію [5]. На підтвердження клінічно доведених і важливих антиоксидантних та протизапальних ефектів $\mathrm{H}_{2}$ він також має здатність регулювати вироблення оксиду азоту і послаблювати його несприятливий вплив [5].

На сьогодні $\mathrm{H}_{2}$ як газ дляінгаляцій використовують як мінімум у чотирьох клінічних дослідженнях [34]. Доктор Чжун Наньшань (епідеміолог, який виявив коронавірус ГРВІ у 2003 р.) на основі попередніх клінічних даних нещодавно рекомендував інгаляцію молекулярного водню пацієнтам з COVID-19 [35]. Таке лікування молекулярним воднем у пілотному дослідженні привело до значного зменшення задишки в більшості пацієнтів з COVID-19. Відповідно, ін- галяцію водню включено як рекомендацію до протоколу Національної комісії охорони здоров'я Китайської Народної Республіки щодо COVID-19 [36]. Незважаючи на те, що їх дослідження стосуються вдихання молекулярного водню, випивання водневої води також $є$ ефрективним, а в деяких випадках - навіть більш ефективним $[37,38]$.

В Україні дослідження значення молекулярного водню для організму в нормі та при патологічних станах починають розвиватися на основі власних розробок генераторів-іонізаторів молекулярного водню, які вже дають перспективні результати $[39,40]$.

Узагальнюючи викладене вище, можна у вигляді схеми зобразити патогенетичні й біохімічні механізми впливу $\mathrm{H}_{2}$ і $\mathrm{NO}$; які разом пригнічують окиснювальний стрес та запалення, індуковані COVID-19, що допомагає запобігти поліорганній недостатності й смерті (рис.).

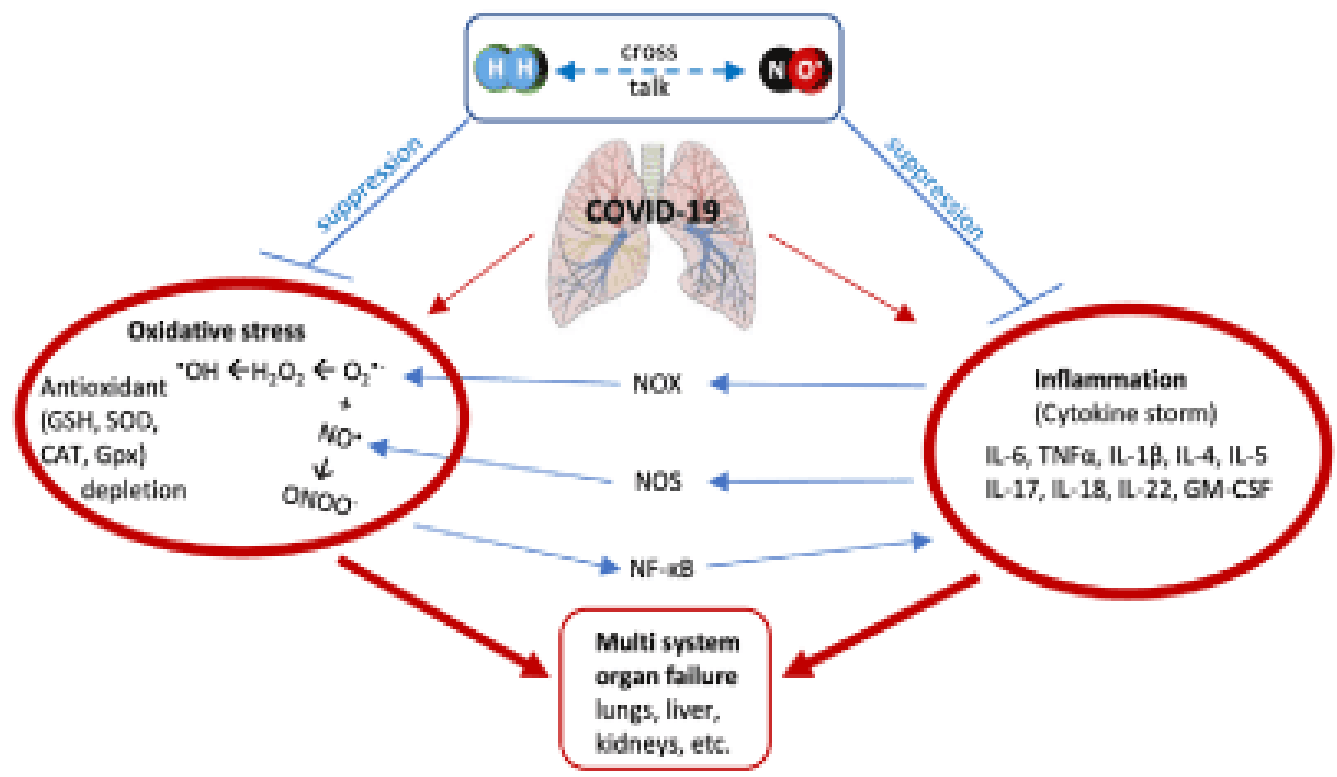

Рис. Схема взаємодії молекулярного водню та оксиду азоту при окиснювальному стресі й запаленні, викликаних COVID-19 [41].

\section{СПИСОК ЛІТЕРАТУРИ}

1. Hui D. S. The continuing 2019-nCoV epidemic threat of novel coronaviruses to global health - The latest 2019 novel coronavirus outbreak in Wuhan, China / D. S. Hui // Int. J. Infect. Dis. - 2020. - 91. - P. 264-266.

2. Suzuki Y. Are the effects of alpha-glucosidase inhibitors on cardiovascular events related to elevated levels of hydrogen gas in the gastrointestinal tract? I Y. Suzuki // FEBS Letters. - 2009. - 583. - P. 2157-2159.
3. Dole M. Hyperbaric hydrogen therapy: a possible treatment for cancer / M. Dole, F. R. Wilson, W. P. Fife // Science - 1975. - 190. - P. 152-154.

4. Ohsawa I. Hydrogen acts as a therapeutic antioxidant by selectively reducing cytotoxic oxygen radicals / I. Ohsawa // Nat. Med. - 2007. - 13. - P. 688-694.

5. LeBaron T. W. A new approach for the prevention and treatment of cardiovascular disorders. Molecular 
hydrogen significantly reduces the effects of oxidative stress / T. W. LeBaron // Molecules. - 2019. - 24.

6. Tamura T. Efficacy of inhaled HYdrogen on neurological outcome following BRain Ischemia During postcardiac arrest care (HYBRID II trial): study protocol for a randomized controlled trial // Trials. -2017. -18. - P. 488

7. Yang M. Hydrogen medicine therapy: An effective and promising novel treatment for multiple organ dysfunction syndrome (MODS) induced by influenza and other viral infections diseases? / M. Yang // SOJ Microbiology \& Infectious Diseases. - 2017. - 5. - P. 1-6.

8. Hu Z. Impact of molecular hydrogen treatments on the innate immune activity and survival of zebrafish (Danio rerio) challenged with Aeromonas hydrophila / Z. Hu // Fish Shellfish Immunol. -2017. - 67. - P. 554-560.

9. Saramago E. A. Molecular hydrogen potentiates hypothermia and prevents hypotension and fever in LPS induced systemic inflammation / E. A. Saramago // Brain. Behav. Immun. - 2019. - 75. - P. 119-128.

10. Spulber S. Molecular hydrogen reduces LPSinduced neuroinflammation and promotes recovery from sickness behaviour in mice / S. Spulber // PLoS One. 2012. - 7. - e42078.

11. Zhao S. Protective effect of hydrogen-rich saline against radiation-induced immune dysfunction / S. Zhao // J. Cell. Mol. Med. - 2014. - 18. - P. 938-946.

12. Akagi J. Hydrogen gas restores exhausted CD8+ $T$ cells in patients with advanced colorectal cancer to improve prognosis / J. Akagi, H. Baba // Oncol. Rep. 2019. - 41. - P. 301-311.

13. Appay V. CD8+ T cell efficacy in vaccination and disease / V. Appay, D. C. Douek, D. A. Price // Nat. Med. 2008. - 14. - P. 623-628.

14. Xia C. Effect of hydrogen-rich water on oxidative stress, liver function, and viral load in patients with chronic hepatitis B / C. Xia // Clin. Transl. Sci. - 2013. - 6. P. 372-375.

15. Itoh T. Molecular hydrogen suppresses FcepsilonRI-mediated signal transduction and prevents degranulation of mast cells / T. Itoh // Biochem. Biophys. Res. Commun. - 2009. - 389. - P. 651-656.

16. toh T. Molecular hydrogen inhibits lipopolysaccharide/interferon gamma-induced nitric oxide production through modulation of signal transduction in macrophages / T. Itoh // Biochemical and Biophysical Research Communications. - 2011. - 411. - P. 143-149.

17. Ren J. D. Molecular hydrogen inhibits lipopolysaccharide-triggered NLRP3 inflammasome activation in macrophages by targeting the mitochondrial reactive oxygen species / J. D. Ren // Biochim. Biophys. Acta. 2016. - 1863. - P. 50-55.

18. Chen H. G. Heme oxygenase-1 mediates the anti-inflammatory effect of molecular hydrogen in LPSstimulated RAW 264.7 macrophages / H. G. Chen // Int. J. Surg. - 2013. - 11. - P. 1060-1066.

19. Bogdan C. Nitric oxide and the immune response / C. Bogdan // Nat. Immunol. - 2001. - 2. - P. 907-916.

20. Akerstrom S. Nitric oxide inhibits the replication cycle of severe acute respiratory syndrome coronavirus / S. Akerstrom // J. Virol. - 2005. - 79. - P. 1966-1969.

21. Wijnands K. A. Arginine and citrulline and the immune response in sepsis / K. A. Wijnands // Nutrients. 2015. - 27. - P. 1426-1463.

22. Torregrossa A. C. Nitric oxide and geriatrics: Implications in diagnostics and treatment of the elderly /
A. C. Torregrossa, M. Aranke, N. S. Bryan // J. Geriatr. Cardiol. - 2011. - 8. - P. 230-242.

23. Schwedhelm E. Pharmacokinetic and pharmacodynamic properties of oral L-citrulline and L-arginine: impact on nitric oxide metabolism / E. Schwedhelm // Br. J. Clin. Pharmacol. - 2008. - 65. - P. 51-59.

24. Ware L. B. Low plasma citrulline levels are associated with acute respiratory distress syndrome in patients with severe sepsis / L. B. Ware // Crit. Care. 2013. - 17. - R10.

25. Pacher $P$. Nitric oxide and peroxynitrite in health and disease / P. Pacher, J. S. Beckman, L. Liaudet // Physiol. Rev. - 2007 - 87. - P. 315-424.

26. Liu H. Combination therapy with nitric oxide and molecular hydrogen in a murine model of acute lung injury / H. Liu // Shock. - 2015. - 43. - P. 504-511.

27. Zhang N. Inhalation of hydrogen gas attenuates airway inflammation and oxidative stress in allergic asthmatic mice / N. Zhang // Asthma Res. Pract. - 2018. 4. - P. 3 .

28. Arnold R. J. A review of the utility and cost effectiveness of monitoring fractional exhaled nitric oxide (FeNO) in asthma management / R. J. Arnold // Manag. Care. - 2018. - 27. - P. 34-41.

29. Khan A. S. Growth hormone increases regional coronary blood flow and capillary density in aged rats I A. S. Khan // J. Gerontol. A Biol. Sci. Med. Sci. - 2001. 56. - P. 364-371.

30. Panthi S. Roles of nitric oxide and ethyl pyruvate after peripheral nerve injury / S. Panthi, K. Gautam // Inflamm. Regener. - 2017. - 37. - 20. - Access mode : https://doi.org/10.1186/s41232-017-0051-8

31. Khaddaj Mallat R. The vascular endothelium: $A$ regulator of arterial tone and interface for the immune system / R. Khaddaj Mallat // Crit. Rev. Clin. Lab. Sci. 2017. - 54. - P. 458-470.

32. Sakai T. Consumption of water containing over $3.5 \mathrm{mg}$ of dissolved hydrogen could improve vascular endothelial function / T. Sakai // Vasc. Health Risk Manag. - 2014. - 10. - P. 591-597.

33. Li Q. Hydrogen water intake via tube-feeding for patients with pressure ulcer and its reconstructive effects on normal human skin cells in vitro / Q. Li // Med. Gas. Res. - 2013. - 3. - P. 20.

34. RefA:https://www.cebm.net/oxford-covid-19 trashed/covid-19-registered-trials-and-analysis/?fbclid=I wAR2TnDJspDYcrF-yeq3cv2wtLTfd7vbglo4VIT340tjz9AN5BiRJJnp-z0

35. RefC: Perspectives of the management of COVID-19 infection in China (EWS webinar serious)

36. RefD: New Coronavirus Pneumonia Diagnosis and Treatment Scheme (Trial Ver7: Mar 3, 2020)

37. Ito M. Drinking hydrogen water and intermittent hydrogen gas exposure, but not lactulose or continuous hydrogen gas exposure, prevent 6-hydorxydopamineinduced Parkinson's disease in rats / M. Ito // Med. Gas. Res. - 2012. - 2. - P. 15.

38. RefB: NCT04290871: Nitric Oxide Gas Inhalation for SARS in COVID-19.(NOSARSCOVID)

39. Покотило О. Стан і перспективи використання молекулярного водню для спортсменів / О. Покотило, І. Захарчук, Б. Вихованець // Спорт. вісн. Придніпров'я. - 2020. - № 1. - С. 443-450.

40. Покотило О. С. Дослідження закономірностей утворення електронодонорної води на основі змін рН 
і ОВП вод в термосах-іонізаторах-генераторах "Living Water" / О. С. Покотило, П. І. Головач, С. О. Покотило // Наук. записки Терноп. нац. пед. ун-ту імені Володимира Гнатюка. Серія "Біологія". - Тернопіль : ТНПУ ім. В. Гнатюка, 2019. - № 4 (78). - С. 24-29.

\section{REFERENCES}

1. Hui, D.S. (2020). The continuing 2019-nCoV epidemic threat of novel coronaviruses to global health The latest 2019 novel coronavirus outbreak in Wuhan, China. Int. J. Infect. Dis., 91, 264-266.

2. Suzuki, Y. (2009). Are the effects of alphaglucosidase inhibitors on cardiovascular events related to elevated levels of hydrogen gas in the gastrointestinal tract? FEBS Letters, 583, 2157-2159.

3. Dole, M., Wilson, F.R., Fife, W.P. (1975). Hyperbaric hydrogen therapy: a possible treatment for cancer. Science, 190, 152-154.

4. Ohsawa, I. (2007). Hydrogen acts as a therapeutic antioxidant by selectively reducing cytotoxic oxygen radicals. Nat. Med., 13, 688-694.

5. LeBaron, T.W. (2019). A New Approach for the Prevention and Treatment of Cardiovascular Disorders. Molecular Hydrogen Significantly Reduces the Effects of Oxidative Stress. Molecules, 24.

6. Tamura, T. (2017). Efficacy of inhaled HYdrogen on neurological outcome following BRain Ischemia During post-cardiac arrest care (HYBRID II trial): study protocol for a randomized controlled trial. Trials, 18, 488.

7. Yang, M. (2017). Hydrogen Medicine Therapy: An Effective and Promising Novel Treatment for Multiple Organ Dysfunction Syndrome (MODS) Induced by Influenza and Other Viral Infections Diseases? SOJ Microbiology \& Infectious Diseases, 5, 1-6.

8. Hu, Z. (2017). Impact of molecular hydrogen treatments on the innate immune activity and survival of zebrafish (Danio rerio) challenged with Aeromonas hydrophila. Fish Shellfish Immunol, 67, 554-560.

9. Saramago, E.A. (2019). Molecular hydrogen potentiates hypothermia and prevents hypotension and fever in LPS-induced systemic inflammation. Brain Behav. Immun., 75, 119-128.

10. Spulber, S. (2012). Molecular hydrogen reduces LPS-induced neuroinflammation and promotes recovery from sickness behaviour in mice. PLoS One, 7, e42078.

11. Zhao, S. (2014). Protective effect of hydrogen-rich saline against radiation-induced immune dysfunction. $J$. Cell Mol. Med., 18, 938-946.

12. Akagi, J., \& Baba, H. (2019). Hydrogen gas restores exhausted CD8+ T cells in patients with advanced colorectal cancer to improve prognosis. Oncol. Rep., 41, 301-311.

13. Appay, V., Douek, D.C., \& Price, D.A. (2008). CD8+ T cell efficacy in vaccination and disease. Nat. Med., 14, 623-628.

14. Xia, C. (2013). Effect of hydrogen-rich water on oxidative stress, liver function, and viral load in patients with chronic hepatitis B. Clin. Transl. Sci., 6, 372-375.

15. Itoh, T. (2009). Molecular hydrogen suppresses FcepsilonRI-mediated signal transduction and prevents
41. LeBaron T. W. A novel functional beverage for COVID-19 and other conditions: Hypothesis and preliminary data, increased blood flow, and wound healing / T. W. LeBaron, M. L. McCullough, K. H. Sr. Ruppman // J. Transl. Sci. - 2019. - 6. DOI: 10.15761/JTS.1000380. degranulation of mast cells. Biochem. Biophys. Res. Commun., 389, 651-656.

16. Itoh, T. (2011). Molecular hydrogen inhibits lipopolysaccharide/interferon gammainduced nitric oxide production through modulation of signal transduction in macrophages. Biochemical and Biophysical Research Communication, 411, 143-149.

17. Ren, J.D. (2016). Molecular hydrogen inhibits lipopolysaccharide-triggered NLRP3 inflammasome activation in macrophages by targeting the mitochondrial reactive oxygen species. Biochim. Biophys. Acta., 1863, 50-55.

18. Chen, H.G. (2013). Heme oxygenase-1 mediates the anti-inflammatory effect of molecular hydrogen in LPS-stimulated RAW 264.7 macrophages. Int. J. Surg., 11, 1060-1066.

19. Bogdan, C. (2001). Nitric oxide and the immune response. Nat. Immunol., 2, 907-916.

20. Akerstrom, S. (2005). Nitric oxide inhibits the replication cycle of severe acute respiratory syndrome coronavirus. J. Virol., 79, 1966-1969.

21. Wijnands, K.A. (2015). Arginine and citrulline and the immune response in sepsis. Nutrients, 27, 1426-1463.

22. Torregrossa, A.C., Aranke, M., Bryan, N.S. (2011). Nitric oxide and geriatrics: Implications in diagnostics and treatment of the elderly. J. Geriatr. Cardiol., 8, 230-242.

23. Schwedhelm, E. (2008). Pharmacokinetic and pharmacodynamic properties of oral L-citrulline and L-arginine: impact on nitric oxide metabolism. Br. J. Clin. Pharmacol., 65, 51-59.

24. Ware, L.B. (2013). Low plasma citrulline levels are associated with acute respiratory distress syndrome in patients with severe sepsis. Crit. Care., 17, R10.

25. Pacher, P., Beckman, J.S., Liaudet, L. (2007). Nitric oxide and peroxynitrite in health and disease. Physiol. Rev., 87, 315-424.

26. Liu, H. (2015). Combination therapy with nitric oxide and molecular hydrogen in a murine model of acute lung injury. Shock, 43, 504-511.

27. Zhang, N. (2018). Inhalation of hydrogen gas attenuates airway inflammation and oxidative stress in allergic asthmatic mice. Asthma. Res. Pract., 4, 3.

28. Arnold, R.J. (2018). A Review of the Utility and Cost Effectiveness of Monitoring Fractional Exhaled Nitric Oxide (FeNO) in Asthma Management. Manag. Care, 27, 34-41.

29. Khan, A.S. (2001). Growth hormone increases regional coronary blood flow and capillary density in aged rats. J. Gerontol. A. Biol. Sci. Med. Sci. 56, B364-B371.

30. Panthi, S., Gautam, K. (2017). Roles of nitric oxide and ethyl pyruvate after peripheral nerve injury. Inflamm. Regener., 37, 20. Retrieved from: https://doi. org/10.1186/s41232-017-0051-831. 
31. Khaddaj, Mallat, R. (2017). The vascular endothelium: A regulator of arterial tone and interface for the immune system. Crit. Rev. Clin. Lab. Sci., 54, 458-470.

32. Sakai, T. (2014). Consumption of water containing over $3.5 \mathrm{mg}$ of dissolved hydrogen could improve vascular endothelial function. Vasc. Health. Risk. Manag., 10, 591-597.

33. Li, Q. (2013). Hydrogen water intake via tubefeeding for patients with pressure ulcer and its reconstructive effects on normal human skin cells in vitro. Med. Gas. Res. 3, 20.

34. Ref A: https://www.cebm.net/oxford-covid-19 trashed/covid-19-registered-trialsand-analysis/? fbclid= IwAR2TnDJspDYcrF-yeq3cv2wtLTfd7vbglo4VIT340tjz9AN5BiRJJnp-z0.

35. Ref C: Perspectives of the management of COVID-19 infection in China (EWS webinar serious).

36. Ref D: New Coronavirus Pneumonia Diagnosis and Treatment Scheme (Trial Ver7: Mar 3, 2020).

37. Ito, M. (2012). Drinking hydrogen water and intermittent hydrogen gas exposure, but not lactulose or continuous hydrogen gas exposure, prevent 6-hydorxydopamine-induced Parkinson's disease in rats. Med. Gas. Res., 2, 15.
38. Ref B: NCT04290871: Nitric Oxide Gas Inhalation for SARS in COVID-19. (NOSARSCOVID).

39. Pokotylo, O., Zakharchuk, I., \& Vykhovanets, B. (2020). Stan i perspektyvy vykorystannia molekuliarnoho vodniu dlia sportsmeniv [Status and prospects of using molecular hydrogen for athletes]. Sportyvnyi visnyk Prydniprovia - Sport Bulletin of Prydniprovia, [in Ukrainian].

40. Pokotylo, O.S., Holovach, P.I., \& Pokotylo, S.O. (2019). Doslidzhennia zakonomirnostei utvorennia elektronodonornoi vody na osnovi zmin rN i OVP vod v termosakh-ionizatorakh-heneratorakh "Living Water" [Research of regularities of electron-donor water formation on the basis of changes of $\mathrm{pH}$ and ORP of waters in thermoses-ionizers-generators "Living Water"]. Naukovi zapysky Ternopilskoho natsionalnoho pedahohichnoho universytetu imeni Volodymyra Hnatiuka. Ser. Biolohiia Scien. Notes of Ternopil Nat. Ped. By Volodymyr Hnatiuk University. Biology Series. Ternopil: TNPU by V. Hnatiuk [in Ukrainian].

41. LeBaron, T.W., McCullough, M.L., \& Ruppman, Sr.K.H. (2019). A novel functional beverage for COVID-19 and other conditions: Hypothesis and preliminary data, increased blood flow, and wound healing. J. Transl. Sci., 6, DOI: 10.15761/JTS.1000380.

\section{О. С. Покотило ${ }^{1}$, М. М. Корда ${ }^{2}$, Ю. С. Кравчук ${ }^{2}$ ТЕРНОПОЛЬСКИЙ НАЦИОНАЛЬНЫЙ ТЕХНИЧЕСКИЙ УНИВЕРСИТЕТ ИМЕНИ ИВАНА ПУЛЮЯ ТЕРНОПОЛЬСКИЙ НАЦИОНАЛЬНЫЙ МЕДИЦИНСКИЙ УНИВЕРСИТЕТ ИМЕНИ И. Я. ГОРБАЧЕВСКОГО}

МОЗ УКРАИНЫ

\section{РОЛЬ МОЛЕКУЛЯРНОГО ВОДОРОДА И ОКСИДА АЗОТА В ПАТОГЕНЕЗЕ COVID-19}

\section{Резюме}

Вступление. В статье представлен обзор научной литературы относительно биохимической роли двух молекул, таких, как молекулярный водород и оксид азота, в первую очередь при COVID-19 - вирусной инорекции, которая может быть летальным заболеванием для людей с ослабленным иммунитетом. Результаты многочисленных доклинических и клинических исследований показали, что газообразные молекулы (молекулярный водород и оксид азота) обладают антиоксидантными, противовоспалительными и иммуномодулирующими преимуществами. Несмотря на то, что оксид азота может непосредственно обезвреживать патогены, чем раскрывает свою определяющую роль для иммунной фрункции, поскольку может ингибировать репликацию вирусов, он способен также вызывать летальное поражение клеток в стрессовых условиях, в частности при COVID-19. В отличие от оксида азота, молекулярный водород имеет очень высокую степень безопасности, помогает регулировать выработку оксида азота, его метаболизм и ослабляет его вредное воздействие. На сегодня еще не раскрыто всех точных молекулярных механизмов молекулярного водорода, однако уже известно, что он обеспечивает ряд защитных эфрфектов, модулирует передачу сигнала, влияет на экспрессию генов и изменяет каскады белкового фросфрорилирования. Через эти подтвержденные эфффекты молекулярного водорода можно однозначно квалифицировать его как вспомогательную терапию против COVID-19 и подобных заболеваний. Обе молекулы (молекулярный водород и оксид азота) используют в доклинических и клинических испытаниях для раскрытия биохимических и патогенетических механизмов взаимодействия при различных патологических прочессах, в том числе и при COVID-19.

Цель исследования - проанализировать современные литературные источники о влиянии молекулярного водорода и оксида азота на предотвращение полиорганной недостаточности при COVID-19. 
Выводы. Увеличение количества исследований дает основания надеяться, что в будущем результаты представленных исследований будут иметь практическое применение в клинической медицине. На сегодня еще необходимо выяснить механизмы положительного влияния молекулярного водорода при различных патологических состояниях, в том числе при COVID-19. Поэтому исследования имеют актуальный характер и будут продолжены.

КЛЮЧЕВЫЕ СЛОВА: COVID-19; молекулярный водород; водородная вода; оксид азота; окислительный стресс.

O. S. Pokotylo ${ }^{1}$, M. M. Korda ${ }^{2}$, Yu. S. Kravchuk ${ }^{2}$ TERNOPIL IVAN PULIUI NATIONAL TECHNICAL UNIVERSITY ${ }^{1}$ I. HORBACHEVSKY TERNOPIL NATIONAL MEDICAL UNIVERSITY²

\section{THE ROLE OF MOLECULAR HYDROGEN AND NITROGEN OXIDE IN THE PATHOGENESIS OF COVID-19}

\section{Summary}

Introduction. The article presents a review of the scientific literature about the biochemical role of two molecules molecular hydrogen and nitric oxide, primarily in COVID-19 - a viral infection that can be fatal for people with weakened immune systems. Numerous preclinical and clinical studies have shown that gaseous molecules such as molecular hydrogen and nitric oxide have antioxidant, anti-inflammatory and immunomodulatory benefits. Nitric oxide can directly kill pathogens and this is a key role in immune function because it can inhibit viral replication, it can also cause fatal cell damage under stress, particularly in COVID-19. Unlike nitric oxide, molecular hydrogen has a very high degree of safety and helps to regulate the production of nitric oxide, its metabolism and reduce its harmful effects. To date, not all the exact molecular mechanisms of $\mathrm{H} 2$ have been discovered, but it is already known that it provides a number of protective effects, modulates signal transduction, affects gene expression and alters the cascades of protein phosphorylation. Because of these proven effects of molecular hydrogen, it can be unambiguously qualified as the optimal therapy against COVID-19 and similar diseases. Both of these molecules (nitric oxide, molecular hydrogen) are used in preclinical and clinical trials to reveal the biochemical and pathogenetic mechanisms of interaction in various pathological processes, including COVID-19.

The aim of the study - to analyze modern literature sources on the effect of molecular hydrogen and nitric oxide on the prevention of multiorgan failure in COVID-19.

Conclusion. The growing number of studies gives reason to hope that in the future the results of the presented studies will have practical application in clinical medicine. Thus, today there are still a number of questions to explain the mechanisms of the positive effect of molecular hydrogen in various pathological conditions, including COVID-19. Therefore, the research is relevant and will be continued.

KEY WORDS: COVID-19; molecular hydrogen; hydrogen water; nitric oxide; oxidative stress.

Адреса для листування: О. С. Покотило, Тернопільський національний технічний університет імені Івана Пулюя Мон України, вул. Танцорова, 2, Тернопіль, 46001, Україна, e-mail: Pokotylo_oleg@ukr.net. 